\title{
Incretin Mimetics Vildagliptin and Exenatide Improve Pedicle Skin Flap Survival in Rats
}

\author{
Lyudmila M. Danilenko, Alla P. Tarasova*, Mikhail V. Pokrovskiy, Konstantin S. Trunov, Yulia V. Stepenko, \\ Elena B. Artyushkova and Oleg S. Gudyrev
}

Department of Pharmacology, Medical Institute, Belgorod State University, 85, Pobedy St., Belgorod, 308015, Russia *Corresponding author's Email: tarasova_ap@ mail.ru; ORCID: 0000-0003-1061-0999

\begin{abstract}
Hypoxia and tissue ischemia are the leading factors in the alteration of tissues in many pathological conditions. Prevention and reversion of the effects of local ischemia, which develops during various surgical interventions, is an actual problem of modern medicine. The aim of the present study was to investigate the effect of exenatide and vildagliptin on the survival rate of an isolated pedicle skin flap in sixty adults Wistar rats. Simulation of a pedicle skin graft was performed on the second day of the experiment. After anesthesia under aseptic conditions, a skin graft was cut out: isolated in a plastic bag, the edges of the skin were stitched with interrupted sutures (nylon 3/0). Rats were divided into six groups: control group, exenatide group $(10 \mu \mathrm{g} / \mathrm{kg} / \mathrm{day}$ subcutaneously for nine days after surgery), vildagliptin group $(0.2 \mathrm{mg} / \mathrm{kg} / \mathrm{day}$ intraperitoneally for nine days after surgery) and pentoxifylline group $(100 \mathrm{mg} / \mathrm{kg} /$ day intravenously, two hours before the surgical intervention). In the other two groups, glibenclamide (5 $\mathrm{mg} / \mathrm{kg}$ ) were administered before injection of incretin mimetics. On the third, seventh and tenth day, area of the surviving tissue was measured. Subsequently, the survival rate of the skin graft was calculated. The area of the surviving tissue in exenatide and vildagliptin group was 1.5 and 1.7 times more compared to the control group, respectively. Preliminary blockade of ATP-dependent potassium channels by glibenclamide eliminated the protective effect of exenatide and vildagliptin. The increase in the survival of ischemic tissues using exenatide and vildagliptin has been experimentally proved. The current study confirmed the important role of ATP-dependent potassium channels in dermatoprotective properties of incretin mimetics.
\end{abstract}

Key words: Dermatoprotective properties, Exenatide, Ischemia, Pedicle skin graft, Vildagliptin.

\section{INTRODUCTION}

In the modern view, ischemic-reperfusion injury is the leading cause of most of the critical situations that are somehow associated with ischemia including myocardial infarction, stroke, organ transplantation, and shock of various etiologies (Lankin et al., 2005; Sloth et al., 2014; Sharafeev and Bayazitova, 2016). The resumption of blood flow, occurring after ischemia, paradoxically causes deep tissue damage and further cell necrosis (Savas et al., 2003).

At the same time, none of the proposed methods and their combinations provide guaranteed protection against ischemia-reperfusion injury, in connection with which the search and selection of innovative and promising compounds and preparations of this orientation continue. Preclinical studies at the systemic (Korokin et al., 2014; Peresypkina et al., 2016; Yakushev et al., 2016), cellular (Danilenko et al., 2016; Kravchenko et al., 2016; Kalmikov et al., 2018), and molecular (Bogus et al., 2018; Dzhimak et al., 2018; Soldativ et al., 2018) levels, including specific activity (Gumanova et al., 2007; Denisyuk et al., 2016; Danilenko, 2018) and toxicology studies (Kolesnichenko et al., 2018) in conjunction with bioequivalence studies (Kalmikov et al., 2018), therapeutic equivalence and effectiveness (Avdeeva et al., 2016) are an integral part of the research of innovative drugs.

Incretin hormones are secreted in response to food intake and stimulate insulin secretion (Gautier et al., 2008). Glucagon-like peptide-1 (GLP-1) is an incretin hormone secreted by the small intestine to regulate glucose concentration in the blood. GLP-1 stimulates insulin release by binding to the GLP-1 receptor (GLP-1R) on the beta cells of the pancreas. Moreover, stimulation of GLP-1Rs has cytoprotective and anti-apoptosis effects on tissues cells bearing this receptor (Ban et al., 2010; Anagnostis et al., 2011).

The GLP-1R belongs to class B1 (secretin receptor-like) of the family of G-protein-coupled receptors (GPCR). The interaction of GLP-1 with its receptor is accompanied by activation of adenylate cyclase (AC) and followed by an increase in cyclic adenosine monophosphate (cAMP) level and subsequently leading to activation of protein kinase A (PKA), phosphatidylinositol-3-kinase (PI3K), and protein kinase B (PKB, also known as Akt), thereby realizing the effect of GLP-1 on the functioning of target cells, as well as on the processes of apoptosis and regeneration (Deacon et al., 2006; Ban et al., 2010; Wei et al., 2016) because GLP-10 metabolites with respect to GLP-1R. At the same time, according to some studies, metabolites of incretins have their own physiological effects (Deacon et al., 2006; Saraiva and Sposito, 2014). 
In addition to the hypoglycemic effect, there is evidence that GLP-1R agonists and DPP-4 inhibitors have pleiotropic effects (Ban et al., 2008; Vlasov et al., 2016). Due to the fact that the pancreas, brain, heart and other organs have exactly the same type of GLP-1R, it is reasonable to assume that the cytoprotective effect will extend to all types of tissues including skin tissue (Tyurenkov et al., 2017). In this regard, the present study intended to evaluate the efficacy of the incretin mimetic agents including exenatide and vildagliptin in preventing and ameliorating the consequences of ischemia-reperfusion injury.

\section{MATERIALS AND METHODS}

The present study were conducted in laboratory of Medical Institute of Belgorod State University, Belgorod, Russia. The experiments were carried out on 60 adult male rats of the Wistar line weighing 200-250 g. All rats were divided into six groups of 10 animals. Simulation of an isolated pedicle skin flap was performed on the second day of the experiment, according to the findings of Kolesnik (2010). On the abdomen of the rat, the skin was cut off and stepping back $1 \mathrm{~cm}$ from the xiphoid process along the white line of the abdomen. A skin graft was cut off $(1 \times 4 \mathrm{~cm})$ while maintaining the supply vessel. It was placed in an insulated plastic bag and sewn to the skin. Operations were performed under anesthesia with chloral hydrate $(300 \mathrm{mg} / \mathrm{kg}$, intraperitoneally).

To study the cytoprotective effect of exenatide and vildagliptin on the model of an isolated skin graft on the pedicle, all experimental animals were divided into six groups. In the control group, rats did not receive any treatment. In exenatide group, exenatide $(10 \mu \mathrm{g} / \mathrm{kg} / \mathrm{day})$ was injected subcutaneously for 9 days after the operation, rats in vildagliptin group received vildagliptin $(0.2 \mathrm{mg} / \mathrm{kg} /$ day $)$ intraperitoneally for 9 days after the operation. In the other group, pentoxifylline as a drug reference was injected intravenously at a dose of $100 \mathrm{mg} / \mathrm{kg} / \mathrm{day} 2$ hours before the experiment.

To determine the role of ATP-dependent potassium channels in the implementation of the mechanism of action of incretin mimetics, $5 \mathrm{mg} / \mathrm{kg}$ glibenclamide were injected intragastrically through a probe to animals, 30 minutes before drug administration. The areas of surviving tissue were measured on third, seventh and tenth days and eventually, the survival rate of the skin graft was calculated (the ratio of the area of the surviving tissue to the initial area of the graft $x$ $100 \%)$.

\section{Ethical approval}

All of the experimental process was conducted in according to "modern ethical requirements for animal experiments" (Kopaladze, 1999).

\section{RESULTS AND DISCUSSION}

In the control group, the area of the surviving tissue on the fifth day was $1.62 \pm 0.02 \mathrm{~cm}^{2}$, which is $41 \%$ of the original area $\left(4 \mathrm{~cm}^{2}\right)$. The administration of exenatide and vildagliptin led to an increase in the area of the surviving tissue to $2.68 \pm 0.03 \mathrm{~cm}^{2}$ and $2.41 \pm 0.09 \mathrm{~cm}^{2}$, respectively. In the group of pentoxifylline $(100 \mathrm{mg} / \mathrm{kg} / \mathrm{day})$, surviving graft area was $1.81 \pm 0.07 \mathrm{~cm}^{2}$, which is 1.1 times more than the control group, but less than in exenatide and vildagliptin.

When simulating a skin graft on the pedicle, both studied incretin mimetics contributed to a significant increase in the area of the surviving tissue in comparison with the control group at 3, 7, and 10 days (Table 1). According to the obtained results, vildagliptin had more beneficial effects on graft survival rate compared to the control group.

In the present study, it was revealed that Preliminary blockade of ATP-dependent potassium channels by glibenclamide eliminates the protective effect of incretin mimetics when simulating a pedicle skin graft in rats. The survival of the skin graft in experimental animals with the administration of glibenclamide did not differ from that of the control group, which confirms the fact that glibenclamide at the applied dose does not affect the survival of ischemic tissues (Table 2). When using glibenclamide before the administration of exenatide and vildagliptin, the area of the surviving tissue was 1.3 and 1.4 times less than with their isolated administration, respectively.

The GLP-1R has been identified in the skin of mice; in cultured skin cells, GLP-1 activates the mitogen-activated protein kinase/extracellular signal-regulated kinase (MAPK/ERK) pathway associated with cell proliferation, differentiation, and cytoprotection (List and $\mathrm{He}, 2006$ ). In this regard, many recent studies have demonstrated the beneficial role of GLP-1 analogs such as exenatide and DPP-4 inhibitors such as vildagliptin in patients with diabetes (Lee and Lee, 2017), as well as promote ulcers healing on the feet (Long et al., 2018) and the healing of diabetic wounds in rodents (Roan et al., 2016). In addition, DPP-4 expression is increased in dermal fibroblasts of mouse muscle after skin damage (Schürmann et al., 2012) and is a prerequisite for fibroblast migration and proliferation, indicating the role of regional incretins in regulating fibroblast functions and, possibly, wound healing. Recent experimental findings indicated the possible role of incretins in promoting tissue regeneration and, therefore, their ability to stimulate the migration of endothelial cells (Kang et al., 2013) to inhibit apoptosis (Favaro et al., 2012) and reduce inflammation and oxidative stress during ischemia (Gurtner et al., 2008). 
Most researchers talk about the connection of the GLP-1R with the most important intracellular signaling cascades - PI3K/PKB (Akt), AC/PKA/MAPK, PKB (MAPK)/NF- $\kappa B$ and PKB (PKA)/eNOS. GLP-1R agonists (including liraglutide and exenatide) are able to have an endothelium protective effect in diabetes mellitus, reducing the activation of many pro-inflammatory mediators and adhesion-enhancing factors (including TNF $\alpha$, PAI-1, VCAM-1, ICAM-1, MCP-1 and E-selectin) which stimulate adhesion and infiltration of the vascular wall by monocytes and macrophages and are associated with endothelial dysfunction and atherogenesis (Stewart et al., 2015; Jiang et al., 2018).

Nevertheless, there is no consensus in the literature in explaining the mechanism of the cytoprotective action of incretin mimetics. A number of studies suggest the implementation of a protective effect of incretin mimetics according to the type of ischemic preconditioning, where the mitochondrial ATP - dependent potassium channels can be considered as the final effector link, the activation of which directly leads to an increase in resistance during ischemia (Tamareille et al., 2011; Ussher and Drucker, 2012).

Table 1. Indicators of skin graft survival rates when using exenatide, vildagliptin, and pentoxifylline in male rats.

\begin{tabular}{lccc}
\hline \multirow{2}{*}{ Medicaments (dose; number of members) } & \multicolumn{3}{c}{ Necrosis area of the skin graft $(\%)$} \\
\cline { 2 - 4 } & Day 3 & Day 7 & Day 10 \\
\hline Control group (saline) & $30.98 \pm 3.2$ & $65.76 \pm 2.4$ & $84.55 \pm 3.3$ \\
Exenatide $(10 \mu \mathrm{g} / \mathrm{kg} / \mathrm{day} ; 10)$ & $27.37 \pm 3.1^{*}$ & $52.9 \pm 4.4^{*}$ & $61.8 \pm 3.5^{*}$ \\
Vildagliptin $(0.2 \mathrm{mg} / \mathrm{kg} /$ day; 10) & $24.1 \pm 2.8^{*}$ & $44.3 \pm 3.1^{*}$ & $59.1 \pm 2.4^{*}$ \\
Pentoxifylline $(100 \mathrm{mg} / \mathrm{kg} /$ day; 10) & $36.9 \pm 1.9^{*}$ & $39.5 \pm 3.8^{*}$ & $67.8 \pm 2.4^{*}$ \\
\hline
\end{tabular}

*significant different $(\mathrm{p}<0.05)$ compred to the control group. Values are expressed as mean \pm standard deviation

Table 2. Protective effect of exenatide and vildagliptin in the background of glibenclamide on skin graft survival rate.

\begin{tabular}{lccc}
\hline \multirow{2}{*}{ Medicaments (dose; number of members) } & \multicolumn{2}{c}{ Necrosis area of the skin graft $(\%)$} \\
\cline { 2 - 4 } Control group: saline $(10)$ & Day 3 & Day 7 & Day 10 \\
Exenatide $(10 \mu \mathrm{g} / \mathrm{kg} / \mathrm{day} ; 10)$ & $30.9 \pm 3.2$ & $65.7 \pm 2.4$ & $84.5 \pm 3.3$ \\
Glibenclamide $(5 \mathrm{mg} / \mathrm{kg} ; 10)$ & $27.3 \pm 3.1^{*}$ & $52.9 \pm 4.4^{*}$ & $61.8 \pm 3.5^{*}$ \\
Glibenclamide $(5 \mathrm{mg} / \mathrm{kg})+$ Exenatide $(10 \mu \mathrm{g} / \mathrm{kg} / \mathrm{day})(10)$ & $31.0 \pm 2.2$ & $64.3 \pm 3.1$ & $83.9 \pm 2.7$ \\
Vildagliptin $(0.2 \mathrm{mg} / \mathrm{kg} / \mathrm{day} ; 10)$ & $29.1 \pm 2.04$ & $61.7 \pm 2.53$ & $82.5 \pm 3.21$ \\
Glibenclamide $(5 \mathrm{mg} / \mathrm{kg})+$ Vildagliptin $(0.2 \mathrm{mg} / \mathrm{kg})(10)$ & $24.1 \pm 2.8^{*}$ & $44.3 \pm 3.1^{*}$ & $59.1 \pm 2.4^{*}$ \\
\end{tabular}

*Significant different $(\mathrm{P}<0.05)$ compred to the control group. Values are expressed as mean \pm standard deviation

\section{CONCLUSION}

The obtained results in the present research testify the protective effect of exenatide and vildagliptin incretins when simulating a pedicle skin graft, which was accompanied by a decrease in the severity of ischemic tissue damage. The blockade of ATP-dependent potassium channels by glibenclamide on a pedicle skin graft reduced the effects of exenatide and vildagliptin. There is a necessity for further experimental and clinical studies to explain the mechanism for implementing the protective effects of incretins on various models.

\section{DECLARATIONS}

Authors' contributions

All of authors had equal roles in writing, editing, and experimental process and finally checked and approved the last edition of article.

Competing interests

The authors have declared that no competing interest exists.

\section{REFERENCES}

Anagnostis P, Athyros VG, Adamidou F, Panagiotou A, Kita M, Karagiannis A and Mikhailidis DP (2011). Glucagon-like peptide-1based therapies and cardiovascular disease: looking beyond glycaemic control. Diabetes Obesity and Metabolism, 13(4):302312. DOI: http://dx.doi.org/10.1111/j.1463-1326.2010.01345.X

Avdeeva N, Kulikov A, Pokrovskii M and Avtina T (2016). Pharmacokinetic studies of new antiparkinsonian drug rapitalam. Research Results in Pharmacology, 2(4): 3-8. DOI: http://dx.doi.org/10.18413/2500-235X-2016-2-4-3-8 
Bacci S, Laurino A, Manni ME, Landucci E, Musilli C, Siena G, Mocali A and Raimondi L (2015). The pro-healing effect of exendin4 on wounds produced by abrasion in normoglycemic mice. European Journal of Pharmacology, 764:346-352. DOI: http://dx.doi.org/10.1016/j.ejphar.2015.06.056

Ban K, Kim KH, Cho CK, Cho, CK, Sauve M, Diamandis E, Backx PH, Drucker DJ and Husain M (2010). Glucagon-like peptide (GLP) - 1(9-36) amide-mediated cytoprotection is blocked by exendin (9-39) yet does not require the known GLP-1 receptor. Endocrinology, 151(4):1520-1531. DOI: http://dx.doi.org/10.1210/en.2009-1197.

Ban K, Noyan-Ashraf MH and Hoefer J (2008). Cardioprotective and vasodilatory actions of glucagon-like peptide 1 receptor are mediated through both glucagon-like peptide 1 receptor-dependent and -independent pathways. International Journal of Cardiology, 118(4): 2340-50. DOI: http://dx.doi.org/10.1161/circulationaha.107.739938.

Bogus S, Galenko-Yaroshevsky P, Suzdalev K, Sukoyan G, Abushkevich V and Soldatov V (2018). 2-phenyl-1-(3-pyrrolidin-1-ilpropyl)-1H-indole hydrochloride (SS-68): Antiarrhythmic and Cardioprotective Activity and Its Molecular Mechanisms of Action (Part II). Research Results in Pharmacology, 4(3):73-86. DOI: http://dx.doi.org/10.3897/rrpharmacology.4.30329

Danilenko L, Klochkova G, Kizilova I and Pokrovskii M (2016). Metabolic cardioprotection: new concepts in implementation of cardioprotective effects of meldonium. Research Results in Pharmacology, 2(3): 95-100. DOI: http://dx.doi.org/10.18413/2500235X-2016-2-3-95-100

Danilenko LM (2018). Doxorubicin-associated Cardiomyopathy: New Approaches to Pharmacological Correction Using 3-(2,2,2trimethylhydrazinium) Propionate Derivatives. Research Results in Pharmacology, 4(1): 81-86. DOI: http://dx.doi.org/10.3897/rrpharmacology.4.25530

Deacon CF, Plamboeck A and Rosenkilde MM (2006). GIP-(3-42) does not antagonize insulinotropic effects of GIP at physiological concentrations. American Journal of Physiology-Endocrinology and Metabolism, 291(3): 468-475. DOI: http://dx.doi.org/10.1152/ajpendo.00577.2005

Denisyuk T, Lazareva G, Provotorov V and Pokrovskaya T (2016). Endothelium and cardioprotective effects of HMG-Co-Areductase in combination with L-arginine in endothelial dysfunction modeling. Research Results in Pharmacology, 2(1): 4-8. DOI: http://dx.doi.org/10.18413/2313-8971-2016-2-1-4-8

Dzhimak SS, Basov AA, Elkina AA, Fedulova LV, Kotenkova EA, Vasilevskaya ER, Lyasota OM and Baryshev MG (2018). Influence of deuterium-depleted water on hepatorenal toxicity. Jundishapur Journal of Natural Pharmaceutical Products, 13: e69557. DOI: http://dx.doi.org/10.5812/jjnpp.69557.

Favaro E, Granata R, Miceli I, Baragli A, Settanni F, Cavallo Peri P, Ghigo E, Camussi G, Zanone MM (2012). The ghrelin gene products and exendin- 4 promote survival of human pancreatic islet endothelial cells in hyperglycaemic conditions, through phosphoinositide 3-kinase/Akt, extracellular signal-related kinase (ERK)1/2 and cAMP/protein kinase A (PKA) signalling pathways. Diabetologia, 55:1058-1070. DOI: http://dx.doi.org/10.1007/s00125-011-2423-y.

Gautier J, Simeon pierre C and Girard J (2008). Physiology of incretins (GIP and GLP-1) and abnormalities in type 2 diabetes. Diabetes \& Metabolism, 34: 65-72. DOI: http://dx.doi.org/10.1016/S1262-3636(08)73397-4.

Gumanova NG, Artyushkova EB, Metel'skaya VA, Kochkarov VI, Pokrovskaya TG, Danilenko LM and Pashin EN (2007). Effect of antioxidants pQ510 and resveratrol on regulatory function of the endothelium in rats with modeled arterial hypertension. Bulletin of Experimental Biology and Medicine, 143(6), 678-681. DOI: http://dx.doi.org/10.1007/s10517-007-0212-x

Gurtner GC, Werner S, Barrandon Y and Longaker MT (2008). Wound repair and regeneration. Nature, 453:314-321

Jiang WJ, Peng YC and Yang KM (2018). Cellular signaling pathways regulating $\beta$-cell proliferation as a promising therapeutic target in the treatment of diabetes. Experimental and Therapeutic Medicine, 16(4):3275-3285. DOI: http://dx.doi.org/10.3892/etm.2018.6603

Kalmykov V, Kusov P, Yablonskaia M, Korshunov E, Korshunova D, Kubekina M, Silaeva Y, Deykin A and Lukyanov N (2018). New personalized genetic mouse model of Lesch-Nyhan syndrome for pharmacology and gene therapy. Research Results in Pharmacology, 4(4):97-104. DOI: http://dx.doi.org/10.3897/rrpharmacology.4.32209

Kang HM, Kang Y, Chun HJ, Jeong JW and Park C (2013). Evaluation of the in vitro and in vivo angiogenic effects of exendin-4. Biochemical and Biophysical Research Communications, 434:150-154. DOI: http://dx.doi.org/10.1016/j.bbrc.2013.03.053

Kolesnichenko PD, Gudyrev OS, Zhuchenko MA, Zhernakova NI, Faitelson AV, Pershina MA, and Soldatov VO. (2018). Evaluation of carbamylated darbepoetin acute toxicity. International Journal of Research in Pharmaceutical Sciences, 9 (3):725-730. DOI: http://dx.doi.org/10.26452/ijrps.v9i3.1553

Kolesnik IM (2010). Effect of distant preconditioning and recombinant erythropoietin on the survival of ischemic tissues and neovasculogenesis (experimental study): Thesis in Candidate Medical Sciences: 14.03.06 / I. M. Kolesnik, Kursk, Russia, p.21.

Kopaladze RA (1999). I. P. Pavlov on vivisection and the modern ethical requirements for animal experiments. Zh Vyssh Nerv Deiat Im I P Pavlova 49(4):589-99. PMID: 10512020

Korokin MV, Pokrovskii MV, Kochkarov VI, Gudyrev OS, Korokina LV, Pokrovskaya TG and Gureev VV (2014). Endothelial and cardio protective effects of tetrahydrobiopterin, L-norvaline, L-arginine and their combinations by simulation of hyperhomocysteine induced endothelial dysfunction. Research Journal of Pharmaceutical, Biological and Chemical Sciences, 5(6), 13751379 .

Kravchenko D, Beskhmelnitsyna E, Korokin M, Avtina T, Sernov L, Tishin A and Kostina D (2016). Molecular screening of prospective candidates for TRPA1 ion channel selective antagonists. Research Results in Pharmacology, 2(1): 63-66. DOI: http://dx.doi.org/10.18413/2313-8971-2016-2-1-63-66

Lankin VZ, Lisina MO, Arzamastseva NE, Konovalova GG, Nedosugova LV, Kaminny AI, Tikhaze AK, Ageev FT, Kukharchuk VV and Belenkov YU (2005). Oxidative stress in atherosclerosis and diabetes. Bulletin of Experimental Biology and Medicin, 140(7):48-51. 
Lee S and Lee DY (2017). Glucagon-like peptide-1 and glucagon-like peptide-1 receptor agonists in the treatment of type 2 diabetes. Annals of Pediatric Endocrinology \& Metabolism, 22:15-26. DOI: http://dx.doi.org/10.6065/apem.2017.22.1.15

List JF and He JF (2006). Habener Glucagon-like peptide-1 receptor and proglucagon expression in mouse skin. Regulatory Peptides, 134:149-157. DOI: http://dx.doi.org/10.1016/j.regpep.2006.02.007

Long M, Cai L, Li W, Zhang L, Guo S, Zhang R, Zheng Y, Liu X, Wang M and Zhou X, et al (2018) DPP-4 Inhibitors Improve diabetic wound healing via direct and indirect promotion of epithelial-mesenchymal transition and reduction of scarring. Diabetes 67:518-531. DOI: http://dx.doi.org/10.2337/db17-0934

Peresypkina A, Gubareva V, Levkova E and Shabelnikova A (2016). Correction of retinal angiopathy of hypertensive type by minoxidil, sildenafil in experiment. Research Results in Pharmacology, 2(4):34-44. DOI: http://dx.doi.org/10.18413/2500235X-2016-2-4-34-44

Roan JN, Cheng HN, Young CC, Lee CJ, Yeh ML, Luo CY, Tsai YS and Lam CF (2016). Exendin-4, a glucagon-like peptide-1 analogue, accelerates diabetic wound healing. Journal of Surgical Research, 208:93-103. DOI: http://dx.doi.org/10.1016/j.jss.2016.09.024

Saraiva F and Sposito AC (2014). Cardiovascular effects of Glucagon-like peptide 1 (GLP-1) receptor agonists. Cardiovascular Diabetology, 13:142. DOI: http://dx.doi.org/10.1186/s12933-014-0142-7.

Savas C, Ozogul C, Karaöz N, Delibas N and Ozgüner F (2003). Splenectomy reduces remote organ damage after intestinal ischaemia-reperfusion injury. Acta chirurgica Belgica, 103(3):315-320.

Schürmann C, Linke A, Engelmann-Pilger K, Steinmetz C, Mark M, Pfeilschifter J and Klein S (2012). The dipeptidyl peptidase-4 inhibitor linagliptin attenuates inflammation and accelerates epithelialization in wounds of diabetic ob/ob mice. Journal of Pharmacology and Experimental Therapeutics, 342: 71-80. DOI: http://dx.doi.org/10.1124/jpet.111.191098

Seo E, Lim JS, Jun JB, Choi W, Hong IS and Jun HS (2017). Exendin-4 in combination with adipose-derived stem cells promotes angiogenesis and improves diabetic wound healing. Journal of Translational Medicine, 15:35. DOI: http://dx.doi.org/10.1186/s12967-017-1145-4

Sharafeev A and Bayazitova VA (2016). Reperfusion injury in acute myocardial infarction. Diary of the Kazan Medical School, 4 (14): 49-53.

Sloth AD, Schmidt MR, Munk K, Kharbanda RK, Redington AN, Schmidt M, Pedersen L, Sorensen HT, and Botker HE (2014). Improved long-term clinical outcomes in patients with ST-elevation myocardial infarction undergoing remote ischaemic conditioning as an adjunct to primary percutaneous coronary intervention. European Heart Journal, 35(3):168-175.

Soldatov VO, Shmykova EA, Pershina MA, Ksenofontov AO, Zamitsky YM, Kulikov AL, Peresypkina AA, Dovgan AP and Belousova YV (2018). Imidazoline receptors agonists: possible mechanisms of endothelioprotection. Research Results in Pharmacology, 4(2):1118. DOI: http://dx.doi.org/10.3897/rrpharmacology.4.27221

Stewart AF, Hussain MA, García-Ocaña A, Vasavada RC, Bhushan A, Bernal-Mizrachi E and Kulkarni RN (2015). Human $\beta$-cell proliferation and intracellular signaling: part 3. Diabetes, 64(6):1872-1885. DOI: http://dx.doi.org/10.2337/db14-1843

Tamareille S, Mateus V, Jeanneteau J, Croue A, Henrion D, Furber A and Prunier F (2011). Risk and Safe signaling pathway interactions in remote limb ischemic preconditioning in combination with local ischemic postconditioning Ghaboura. Basic Research in Cardiology, 106:1329-1339. DOI: http://dx.doi.org/10.1007/s00395-011-0210-z

Tyurenkov IN, Bakulin DA, Kurkin DV and Volotova EV (2017). Cardiovascular Effects of Incretin-Based Therapies and Their Therapeutic Potential. Vestnik RAMN, 72(1):66-75. DOI: http://dx.doi.org/10.15690/vramn732.

Ussher JR and Drucker DJ (2012). Cardiovascular biology of the incretin system. Endocrine Reviews, 33:187-215. DOI: http://dx.doi.org/10.1210/er.2011-1052

Vlasov TD, Simanenkova AV, Dora SV and Shlyakhto EV (2016). Mechanisms of neuroprotective action of incretinomimetics. Cardiology and Diabetes, 19(1): 16-23.

Wei R, Ma S, Wang C, Ke J, Yang J, Li W, Liu Y, Hou W, Feng X, Wang G and et al (2016). Exenatide exerts direct protective effects on endothelial cells through the AMPK/Akt/eNOS pathway in a GLP-1 receptor-dependent manner. American Journal of Physiology-Endocrinology and Metabolism, 310(11):947-957. DOI: http://dx.doi.org/10.1152/ajpendo.00400.2015.

Yakushev V, Filippenko N, Kizilova I, Korokin M, Beskhmelnitsyna E and Litvinova A (2016). Studying dose-dependent endothelioand cardioprotective activity of selective arginase II inhibitor in hyperhomocysteine-induced endothelial dysfunction. Research Results in Pharmacology, 2(1):42-45. DOI: http://dx.doi.org/10.18413/2313-8971-2016-2-1-42-45

Zhang H, Xiong Z and Wang J (2016). Glucagon-like peptide-1 protects cardiomyocytes from advanced oxidation protein productinduced apoptosis via the PI3K/Akt/Bad signaling pathway. Molecular Medicine Reports, 13(2):1593-1601. DOI: http://dx.doi.org/10.3892/mmr.2015.4724 